\title{
KOMUNIKASI PREVENTIF RADIKALISME AGAMA PADA MAHASISWA DI PERGURUAN TINGGI KOTA AMBON
}

\author{
Hakis \\ Institur Agama Islam Negeri Ambon \\ hakis@gmail.com
}

\begin{tabular}{l}
\hline Article Info \\
\hline Article history: \\
Received 3 Agustus 2020 \\
Accepted 17 Agustus 2020 \\
Published 1 Oktober 2020 \\
\hline
\end{tabular}

\section{Keyword:}

Komunikasi, Preventif, Radikalisme Agama

\begin{abstract}
This article discusses are how religious radicalism preventive communication among students at University of Ambon. This type of research is a qualitative descriptive with a phenomenological approach to investigate social and religious phenomena in university students.

The findings of preventive communication in counteracting religious radicalism in Higher Education are: the communication of the campus academics has not been maximized to students in fostering religious understanding. Every tertiary institution needs to have real student data starting from data on their religious understanding so that they know students who are exposed to religious radicalism. The campus is expected to prepare tutor facilities in communicating preventively about religious radicalism and the dangers it causes.
\end{abstract}

Artikel ini membahas tentang bagaimana komunikasi preventif radikalisme agama pada mahasiswa di Perguruan Tinggi Kota Ambon. Jenis penelitian ini adalah deskriptif kualitatif dengan pendekatan fenomenologi untuk menyelidiki fenomena sosial dan keagamaan pada mahasiswa di perguruan tinggi.

Temuan komunikasi preventif dalam menangkal radikalisme agama di PT adalah: komunikasi sivitas akademika kampus kepada para mahasiswa dalam pembinaan pemahaman keagamaan belum maksimal. Setiap PT perlu mempunyai data riil mahasiswa mulai dari data tentang pemahaman keagamaan mereka sehingga mengetahui mahasiswa yang terpapar oleh radikalisme agama. Pihak kampus diharapkan menyiapkan fasilitas tutor dalam mengkomunikasikan secara preventif tentang radikalisme agama dan bahaya yang ditimbulkannya.

\section{Editorial Office:}

Program Studi Ilmu Komunikasi, Fakultas Dakwah dan Komunikasi, UIN Sunan Ampel Surabaya. Jl. Ahmad Yani 117 Surabaya, Jawa Timur, Indonesia.

Email: jurnalilkom@uinsby.ac.id 


\section{Pendahuluan}

Fundamentalisme, radikalisme, dan terorisme dibenturkan dengan berbagai label Islam dan menjadi isu nasional dan bahkan menjadi isu internasional setelah ISIS menjadi isu dunia. Politisasi agama menjadi fenomena global yang dapat dijumpai dalam semua tradisi agamaagama besar di dunia.

Menurut hasil pemikiran teologi dalam tradisi keagamaan, gerakan fundamentalis merupakan gerakan untuk mengembalikan seluruh prilaku dalam tatanan kehidupan umat Islam kepada al-Quran dan Hadis. Sebutan fundamentalis memang terkadang bermaksud untuk menunjuk kelompok revivalis Islam. Akan tetapi kadangkala istilah fundamentalisme. ${ }^{1}$

Sarjana Barat seperti Geraudy mendefiniskan fundamentalisme hanya berpedoman pada kamus-kamus Barat, bahkan pada kamus Perancis saja. Menurut Geraudy, fundamentalisme didefinisikan oleh kamus Larous kecil (1966) dengan cara umum sekali, yaitu: sikap mereka yang menolak penyesuaian kepercayaan dengan kondisi-kondisi yang baru. Kemudian dalam kamus Larous saku (1979) hanya menerapkan istilah fundamentalis pada kaum Kristen Katolik saja, yaitu sikap pemikiran sebagian orang-orang Katolik yang membenci untuk menyesuaikan diri dengan kondiri kehidupan modern. Selanjutnya dalam kamus Larous besar (1984) tertulis fundemtalisme adalah sikap stagnan dan membeku yang menolak seluruh pertumbuhan dan seluruh

1 Muhammad Imarah, Fundamentalisme dalam Perspektif Pemikiran Barat dan Islam, terj. Abdul Hayyie al-Kattani, Cet. I, (Jakarta: Gema Insani Press, 1999), 25. perkembangan. Mazhab yang konservatif yang membeku dalam masalah keyakinan politik, sementara dalam kamus Larous (1987) tertulis sikap sebagian orang-orang Katolik yang menolak seluruh kemajuan, ketika mereka menisbatkan diri mereka pada turats (warisan lama). ${ }^{2}$

Jika dilihat dari segi teoretis, radikalisme tidak identik dengan kekerasan, termasuk penyandingannya terhadap kelompok agama tertentu. Bila sekadar tataran filosofis dan pemahaman, tentu tidak menjadi masalah karena tidak mengakibatkan kerusakan peradaban manusia. Namun, ketika terjadi perubahan dalam wilayah praksis, biasanya paham radikal ini bermetamorfosis dalam tindakan yang anarkis. Radikalisme dengan menghalalkan cara kekerasan dalam memenuhi keinginan atau kepentingan paham mereka maka inilah yang harus dihindari, dan bahkan dilenyapkan.

Umat Islam yang menganut radikalisme agama lebih cendrung menggunakan kekerasan bila bertentangan dengan paham mereka. Paham ini, di samping tidak sesuai dengan keberadaan Islam sebagai agama rahmatan li al-'alamin, juga bertentangan dengan nilai-nilai Islam Nusantara yang tumbuh dan berkembang di Indonesia yang sangat pluralis dan multikulturalis. Di Maluku pada konflik komunal tahun 1999 terdapat istilah laskar jihad bersorban putih rela mati demi mempertahankan agama Islam, dan sekarang ini laskar jihad tersebu tersebar di seantero Maluku berinteraksi dengan masyarakat sehingga tidak mudah disenyapkan di bumi raja-raja Maluku. Mereka berpaham

2 Geraudy, al-Ushuliyatul Ma'ashirah, ter. Khalil Akhmad Khalil, (Paris: Dar Alam al-Fann, 1992), 13. 
radikal yang sangat patuh menjalankan ajaran agama, namun yang menjadi perhatian termasuk pemerintah adalah ketika melakukan kekerasan atas nama agama dan jika itu terjadi, maka Maluku akan mudah terprovokasi kembali dan rentang konflik. Karena itu, mahasiswa sebagai manusia terpelajar hendaknya dibekali dengan nilainilai keagamaan humanis dengan berlandaskan pada pancasila sebagai dasar Negara agar menjadi pilar di tengah- tengah masyarakat yang multi kompleks dan multi paham. ${ }^{3}$

Disamping itu, radikalisme muncul akibat berbagai sebab, baik yang berkaitan dengan konflik kepentingan, ketidakpuasan terhadap penyelenggara negara, maupun yang berhubungan dengan upaya pemaksaan suatu gagasan atau ideologi negara dan pemerintahan. Menurut Azyumardi Azra, sebelum periode modern umumnya penyebab radikalisme Islam bersifat internal, yaitu respon terhadap berbagai masalah inernal umat Islam seperti penyusutan entitas politik muslim secara drastis dan konflik diantara mereka. Banyak umat muslim meyakini bahwa situasi yang memprihatinkan itu muncul akibat kerusakan moral sosial umat muslim sendiri yang merupakan dampak dari keyakinan dan praktek-praktek agama yang keliru dan mengabaikan ajaran Islam yang murni. Akibatnya sebagian umat muslim lainnya mamandang perlu untuk melakukan pembaruan atau reformasi tidak

\footnotetext{
3 Mokogenta Sihontang, "Aktualisasi Nilainilai Pancasila", Diklat Revolusi Mental Balai Diklat Keagamaan Ambon, September, 92018.

${ }^{4}$ Fathurin Zen, Radikalisme Retoris (Jakarta: Bumen Pustaka Emas, 2012), xxii.
}

hanya dengan cara damai tetapi juga dengan kekerasan (radikal) yang menurut mereka dianggap efektif dengan mendeklarasikan perang terhadap umat muslim yang dipandang telah melewati batas. $^{4}$

Radikalisme adalah kualitas atau pernyataan atau prinsip atau doktrin politik atau perubahan sosial yang mengakar. Radikalisme juga diartikan sebagai orientasi politik kelompok yang mengehendaki perubahan pemerintahan dan masyarakat secara revolusioner. secara sosiologis, radikalisme kerap kali muncul apabila terjadi banyak kontradiksi dalam tata sosial yang ada. Bila masyarakat yang mengalami anomali atau kesenjangan antara nilai-nilai dengan pengalaman, dan para masyarakat tidak mempunyai daya lagi untuk mengatasi kesenjangan itu, maka radikalisme dalam lapisan-lapisan masyarakat, terutama di kalangan anak muda. $^{5}$

Radikalisme di Kota Ambon Propinsi Maluku pada awalnya bermula sejak terjadinya konflik di Maluku pada tahun 1999, menurut sebagaian orang merupakan konflik keagamaan antara Islam dan Kristen. Konflik tersebut merupakan rantai panjang dari adanya ketidakadilan dan marjinalisasi masyarakat akibat kebijakan pemerintah baik kolonial maupun Republik. $^{6}$

Beberapa organisasi keagamaan yang dipersepsi sebagai gerakan radikal di

\footnotetext{
5 Abudin Nata, Peta Keragaman Pemikiran Islam di Indonesia, cet. II, (Jakarta: Rajawali Pres, 2001), 18.

6 Duriana, Studi Terhadap Idiologi Radikalisme Agama Pasca Konflik Maluku, Jurnal Fikratuna 8 no. 2, (Desember, 2016): 109.
} 
Maluku yaitu: Mujahidin, Ahlussunnah wa al-Jamaah (Salafi), KAMMI (Kesatuan Aksi Mahasiswa Muslim Indonesia), dan terakhir Hisbut Tahrir Indonesia (HTI), adalah suatu realitas yang tidak dapat disembunyikan karena jejak-jejaknya dapat terlihat dalam berbagai gerakan seperti gerakan keagamaan maupun gerakan sosialkemasyarakatan. Dari berbagai gerakan radikal yang muncul di Maluku pasca konflik Maluku, ada dua yang memilki basis massa relatif lebih besar dibanding yang lain dengan sisitem organisasi yang cukup teratur dan proyek perjuangan atau gerakan yang cukup jelas yaitu Laskar Jihad Ahlussunnah wa alJama'ah yang sekarang lebih populer dikenal dengan Salafi dan Hizbut Tahrir Maluku. ${ }^{7}$

Kesalahpahaman tentang tafsir jihad, juga dijadikan sebagai alat pembenaran oleh kalangan tertentu yang beraliran keras dalam menjastifikasi Islam untuk melakukan ekspresi paham radikal dengan memakai simbol agama. Sebagaimana yang dinyatakan oleh Yusuf al-Qardhawi dalam bukunya $A l$ Sahwah al-Islamiyyah bayna al-Juhud wa al-Tajarruf, bahwa faktor utama munculnya sikap radikalisme dalam beragama adalah kurangnya pemahaman yang benar dan mendalam atas esensi ajaran agama Islam itu sendiri. Islam hanya dipahami secara dangkal dan parsial. ${ }^{8}$ Kesalahan penafsiran sesungguhnya melahirkan perbedaan dalam

\footnotetext{
${ }^{7}$ Duriana, "Studi terhadap Idiologi," 107.

8 Anzar Abdullah, Gerakan Radikalisme dalam Islam Perspektif Historis, Juni 10, 2019, 400
}

menjalankan syariat agama dan itu tidak hanya belaku dalam agama Islam tetapi sesungguhnya semua agama berpotensi penganutnya berpaham radikal jika ia salah menafsirkan ayat-ayat dalam kitab suci mereka. $^{9}$

Menurut Kusmanto, upaya menentang segala bentuk radikalisme merupakan bagian dari reaksi anti radikalisme. Sebenarnya antiradikalisme muncul sebagai bagian dari keinginan masyarakat. Radikalisme dan kontra radikalisme agama merupakan bentuk baru gerakan sosial keagamaan. Sebagai gerakan sosial, maka merupakan dinamika keagamaan masyarakat yang terorganisir. Pengorganisasiannya untuk mencapai tujuan kehidupan yang relevan dengan nilai-nilai agama, atas dasar pemahaman dan pemaknaan ajaran-ajaran agama yang bersifat transenden. Keragaman agama dan aliran keagamaan dalam masyarakat menyebabkan beragam pula bentuk, strategi dan orientasi gerakan. Akibatnya sering terjadi benturan dan atau menyatu di antara persamaan dan atau perbedaan yang melekat dalam dirinya. Klaim kebenaran (truth claim) sangat menentukan dinamika gerakan sosial keagamaan. Radikalisme dan anti radikalisme merupakan bentuk aktual dari klaim kebenaran. Oleh karena masingmasing memiliki perspektif kebenarannya sendiri-sendiri. ${ }^{10}$

9 Ketua GPM Maluku, "Kiat-Kiat menanggulangi Radikalisme di Maluku," Kegiatan Balai Dilkat Ambon, 10 September 2018.

${ }^{10}$ Kusmanto, Thohir Yuli "Dialektika Radikalisme dan Anti Radikalisme di Pesantren," Jurnal Walisongo 23 No. 1, (2015): 33. https://journal.walisongo.ac.id/index.php/walisong o/article/view/221/202 
Demikian juga pemahaman yang menyatakan bahwa dunia mahasiswa sangat rentang dirasuki paham-paham radikal sehingga beberapa perguruan tinggi dicap sebagai basis radikalisme agama yang mendapat perhatian dari pemerintah. Melihat fenomena ini maka perlu ada strategi bagaimana mengubah pola pikir (mindset) mahasiswa terutama mahasiswa baru oleh pihak pengelolah perguruan tinggi sehingga mahasiswa tidak terpapar radikalisme agama. Yang menjadi pokok kajian dari hasil penelitian ini adalah latar belakang mahasiswa menganut paham radikal dan upaya komunikasi preventif radikalisme agama di perguruan tinggi.

\section{Metode Penelitian}

Tipe dalam penelitian ini adalah deskriptif. Penelitian deskriptif adalah suatu penelitian sekedar untuk menggambarkan suatu variabel yang berkenaan dengan masalah yang diteliti tanpa mempersoalkan hubungan antarvariabel. ${ }^{11}$

Penelitian kualitatif menurut Bogdan dan Taylor yang dikutip oleh Lexy, penelitian kualitatif adalah prosedur penelitian yang menghasilkan data deskriptif berupa kata-kata tertulis/lisan dari orang-orang dan perilaku yang diamati. $^{12}$

Kemudian Nasution juga menyatakan bahwah pada hakekatnya, penelitian kualitatif adalah mengamati orang dalam

${ }^{11}$ Sanapiah Faisal, Format-format Penelitian Sosial, (Jakarta: Rajawali Press, 1992), 18.

${ }^{12}$ Lexy J. Moleong, Metodologi Penelitian Kualitatif. (Bandung: Remaja Rosdakarya, 2000), 3.

${ }^{13}$ Nasution, Metode Penelitian Naturalistik Kualitatif, (Bandung: Tarsito, 2003), 5. lingkungankehidupan, berinteraksi dengan mereka, berusaha memahami bahasa dan tafsiran mereka tentang dunia mereka. ${ }^{13}$

Dalam bentuk penelitian lapangan (field reseach), yaitu penelitian yang dilakukan secara langsung ke objek penelitian dengan partisipan. Partisipan atau informan adalah orang-orang yang diajak berwawancara, diobservasi, diminta memberikan data, pendapat, pemikiran, persepsinya. $^{14}$ Tipe penelitian ini juga memberikan gambaran tentang situasi dan kejadian secara sistematis dan faktual mengenai faktor-faktor, sifat-sifat serta hubungan antara fenomena. ${ }^{15}$ Data-data dalam penelitian ini berupa data kualitatif, yakni kata-kata tertulis atau lisan dari orangorang dan perilaku yang dapat diamati. ${ }^{16}$

Penelitian ini menggunakan pendekatan fenomenologi. Fenomenologi merupakan salah satu pendekatan dalam Penelitian Kualitatif. Pendekatan kualitatif adalah suatu proses penelitian dan pemahaman yang berdasarkan pada metodologi yang menyelidiki suatu fenomena sosial dan masalah manusia. Pada pendekatan ini, peneliti membuat suatu gambaran kompleks, meneliti kata-kata, laporan

14 Sukmadinata, Metodologi Penelitian Kualitatif (Bandung: Remaja Rosdakarya, 2006), 94.

${ }^{15}$ Moleong, Metode Penelitian, 23.

${ }^{16}$ Nana Saodih Sukmadinata, Metode Penelitian Pendidikan, (Bandung: PT. Remaja Rosdakarya, 2005), 219. 
terinci dari pandangan responden, dan melakukan studi pada situasi yang alami. ${ }^{17}$

Fenomenologi berasal dari bahasa Yunani, phainomai, yang berarti "menampak"e dan phainomenon merujuk "pada yang menampake. Istilah fenomenologi diperkenalkan oleh Johann Heinrickh Lambert. Meskipun pelopor fenomenologi adalah Husserl, namun dalam bukunya lebih banyak mengupas ide-ide Schutz (yang tetap berdasar pada pemikiran sang pelopor, Husserl). Terdapat dua alasan utama mengapa Schutz dijadikan centre dalam penerapan metodologi penelitian kualitatif menggunakan studi fenomenologi ini. Pertama, karena melalui Schutz-lah pemikiran dan ide Husserl yang dirasa abstrak dapat dijelaskan dengan lebih gamblang dan mudah dipahami. Kedua, Schutz merupakan orang pertama yang menerapkan fenomenologi dalam penelitian ilmu sosial.Oleh karena itu, buku ini mengupas beberapa pandangan Schutz dan penerapannya dalam sebuah penelitian sosial.

Dalam penelitian ini, peneliti mengamati pergerakan mahasiswa dalam praktik keagamaan sehingga dapat masuk ke dalam dunia interpretasi yang pada objek yang diteliti. Setelah pengamatan lalu mengadakan wawancara pada beberapa mahasiswa yang dianggap aktif dalam melakukan praktik ibadah. Dari hasil pengamatan dan wawancara secara terbuka tersebut dianalisis dengan model Patton dengan berdasarkan urutan data.

17 Creswell JW., Qualitative Inquiry and Research Design; Choosing among Five Traditions (London: Sage Publications, 1998), 15.
Analisis data menurut Patton adalah proses mengatur urutan data, mengorganisasi ke dalam suatu pola, kategori, dan satuan uraian dasar. Adapun proses analisis data dalam penelitian ini dilakukan secara simultan dengan pengumpulan data, artinya peneliti dalam mengumpullkan data juga menganalisis data yang diperoleh di lapangan. ${ }^{18}$

Objek penelitian ini adalah tiga perguruan pinggi, yaitu Universitas Pattimura Ambon, Institut Agama Islam Negeri (IAIN) Ambon, dan Institut Agama Kristen Negeri (IAKN) Ambon.

\section{Hasil dan Pepembahasan}

\section{Latar Belakang Mahasiswa Menganut Radikalisme Agama}

Pada umumnya mahasiswa menganut radikalisme agama dipicu oleh pemahaman ajaran agama yang sempit dari asal sekolah. Keterbatasan pengetahuan keagamaan mahasiswa terkait dengan kurangnya membaca dan mempelajari pendidikan agama di sekolah sehingga pemahaman tentang agama masih sangat dasar dan minim. Dari situlah secara mudah penganut paham radikalis mendekati mahasiswa. Mereka memberikan pemahaman keagamaan kepada mahasiswa yang ditemuinya secara hitam putih, pemahaman agama yang tegas dan sempit.

Hasil wawancara lain mengatakan bahwa mahasiswa menganut radikalisme agama karena ingin mempertahankan ideologi dan menjalankan agamanya dengan baik. Mahasiswa yang mempunyai pemikiran

${ }^{18}$ Lexy J. Moleong, Metodologi Penelitian Kualitatif, (Bandung: Remaja Rosdakarya, 2007), 3. 
tersebut adalah mahasiswa yang sering mengikuti pengajian yang dilakukan oleh kelompok radikalis, seperti pengajian atau halaqah yang dilakukan di masjid kampus sebagai wadah bagi perkumpulan mereka.

Lebih lanjut M. Imdadun Rahmat dalam bukunya, Arus Baru Islam Radikal Transmisi Revivalisme Islam Timur Tengah ke Indonesia, menyebutkan, bahwa ajaran Salafi juga disebarkan melalui majalah dan buku-buku yang diterbitkan oleh kalangan Salafi sendiri termasuk pernerjemahan karya-karya para tokoh besar Salafi dari dunia Arab. Mahasiswa yang sering membaca buku tersebut secara mudah mengikuti paham itu dan memperaktikkan dalam kehidupan kesehariannya.

Hal senada yang dikemukana oleh Anas Saldi seorang peneliti LIPI melalui penelitiannya "Mahasiswa Islam dan Masa Depan Demokrasi Indonesia" menekankan, bahwa faktor penyebab gerakan yang dilakukan oleh sekelompok orang dalam menebar paham radikalisme di kampus antara lain: pertama, latar belakang keagamaan yang dangkal. kedua, ketidaktegasan pihak kampus dalam memberikan pencerahan kepada mahasiswa, ketiga, pemerintah kurang campur tangan dalam penanganan paham radikalisme intelektual, keempat, ketimpangan dalam sektor sosial, ekonomi dan politik.

Persentuhan mahasiswa dengan paham radikal di kampus melalui proses komunikasi dengan ajaran-ajaran radikal yang ada di luar kampus. Pengajian rutin yang dilakukan setiap sekali seminggu. Pada awalnya mahasiswa beralasan mengikuti halaqah karena ingin menambah pengetahuan keagamaan mereka dan ingin melaksanakan ajaran agama dengan baik, tapi pada akhirnya setelah mengikuti pengajian secara rutinitas malah berubah mindset mereka tentang ajaran Islam dengan pemahaman yang eksklusif.

Hal senada yang dikemukakan oleh Menteri Komunikasi dan Informatika, Rudiantara, bahwa paham radikalisme di perguruan tinggi tidak dapat dihindarkan lagi, terlebih dengan semakin berkembangnya teknologi. Kelompok radikal memiliki alasan yang tepat untuk menggunakan saluran media sosial sebagai saluran dakwah dengan sejumlah argumen. Pertama, saluran-saluran media sosial sejauh ini adalah paling populer dan paling banyak diminati kaum muda dengan target yang dituju oleh kaum radikalis sangat memungkinkan informasi tersebut dapat tersebar dari kelompok mereka menjadi bagian dari arus utama.

Kedua, saluran media sosial yang mudah digunakan sangat praktis dan gratis. Akhirnya, jejaring sosial memungkinkan kelompok radikal untuk menjangkau audiens yang lebih banyak, target mereka menembus batas-batas fisik secara personal, berbeda dengan model lama laman website di mana mereka harus menunggu pengunjung untuk datang kepada mereka. Tujuan utama kelompok radikal dalam menyebarkan informasi melalui media online adalah untuk tujuan propaganda, radikalisasi, dan rekrutmen.

Pada prinsipnya media sosial memungkinkan kelompok radikal untuk menggunakan strategi penargetan yang dikenal sebagai narrowcasting. Narrowcasting yang bertujuan untuk menyampaikan pesanpesan agama pada segmen tertentu. Metodemetode inilah sangat memungkinkan kelompok 
radikal untuk menargetkan pengguna media sosial terutama yang berusia muda.

Saat ini betapa banyak perguruan tinggi yang mendapatkan pengakuan dan reputasi tinggi tetapi di balik itu mereka terpapar paham radikal. Perguruan tinggi memang wajib menyuguhkan kualitas akademik dan nilai akreditasi yang baik tetapi harus juga menyuguhkan ketenangan dalam perkuliahan, ketidakbimbangan memilih pekerjaan ketika sudah menjadi alumni dari perguruan tinggi. Pada umumnya alumni yang kecewa tidak heran ketika ditemui alumni dari perguruan tinggi bergabung kepada kelompok-kelompok yang mempunyai pemikiran bahwa negara ini tidak ada lagi rasa keadilan.

Kampus-kampus hendaknya aktif menggelar stadium general (kuliah umum), seminar, atau pertemuan ilmiah dalam rangka menangkal paham radikalisme dan terorisme. Hal itu akan senantiasa mengingatkan para mahasiswa sekaligus bentuk kontra-radikalisme sehingga setiap mahasiswa tidak was-was terhadap berbagai propaganda yang mengarah ke radikalisme dan terorisme.

Tindak lanjut dari hasil penelitian ini adalah harus ada gerakan anti-paham radikal di perguruan tinggi yang disuplai dana dari pemerintah, karena mahasiswa tidak memiliki dana tetapi mempunyai power yang sangat potensial, mahasiswa mempunyai ide dalam melakukan aksi anti-paham radikal atau anti paham yang ekstrim dalam beragama.

\section{Komunikasi Preventif Radikalisme Agama di Perguruan Tinggi}

Salah satu upaya menangkal paham radikal adalah hendaknya pemerintah dalam penyusunan kurikulum agama dari TK, SD, SMP, dan SMA dan bahkan sampai pada perguruan tinggi wajib menghindari konten kurikulum yang dapat menyebabkan peserta didik berpaham eksekutif pada ajaran agama. Kurikulum yang disusun hendaknya diboboti dengan pemahaman keagamaan yang toleran, inklusif, pluralis, dan multikultural.

Perguruan tinggi hendaknya malakukan komunikasi preventif dalam menyikapi radikalisme agama tidak berlaku pasif, antipati, dan hanya berfokus mengejar nilai akademik tanpa memedulikan ancaman yang merongrong nilai-nilai Pancasila. Kita harus berani menjalin kerjasama dan menjunjung tinggi persaudaraan dengan umat agama lain, karena negara Indonesia sudah ditakdirkan mengakui beberapa agama dan itu harus dirawat dalam mewujudkan perdamaian dan persatuan anak bangsa.

Terkait dengan hal tersebut di atas, sangat diperlukan peran pemerintah pada perguruan tinggi dalam upaya menanamkan nilai-nilai dasar Pancasila dalam kegiatan sebagai berikut: Pertama, merestorasi kembali nilai-nilai Pancasila khususnya kepada kalangan mahasiswa melalui pembuatan blue print. Pemerintah Pusat berkoordinasi dengan Kemendiknas, Kemenriset dikti, Kementerian Agama dan lainnya dalam pengaktifan kembali nilainilai ajaran Pengamalan Pancasila. Kedua, secara preventif pemberian bimbingan kepada mahasiswa baru tentang pemahaman 
keagamaan sebelum terkontaminasi oleh kelompok radikalis yang merasuk ke dalam kampus dengan berbagai cara.

Hal ini sesuai dengan pernyataan Rektor Universitas Paramadina, Prof. Dr. Firmanzah, bahwa salah satu instrumen dalam upaya menangkal radikalisme agama di perguruan tinggi adalah instrumen intruksi, maksudnya ada struktur komando dari kementerian riset teknologi serta kementerian agama kepada rektor selanjutnya kepada dosen terkait dengan pencegahan radikalisme agama tersebut, namun tidak bersifat otoriter melainkan mengedepankan dialog. ${ }^{19}$ Dengan cara dialog inilah mahasiswa diharapkan banyak mendapatkan pencerahan sekaligus dapat menyampaikan ide-ide cemerlang dalam rangka membantu pemerintah dalam menanggulangi paham-paham radikal yang merusak tatanan masyarakat dan memecah belah keutuhan NKRI.

Hasil dari penelitian ini menyebut bahwa langkah preventif menangkal radikalisme agama pada mahasiswa sebaiknya dilakukan pada saat penjemputan penerimaan mahasiswa baru masuk kampus. Rektor mengintruksikan kepada para dosen terutama kepada Badan Eksekutif Mahasiswa (BEM) dan seterusnya kepada pengurus-pengurus Unit Kegiatan Mahasiswa (UKM) yang lainnya menjemput mahasiswa dengan menunjukkan pemahaman agama yang moderat atau inklusif. Jangan membiarkan mahasiswa baru itu jatuh kepada tangantangan yang berpaham radikal. Karena itu mahasiswa baru bagaikan kertas putih yang belum ternodai terutama dari sekolah umum yang notabene pelajaran agama mereka masih dangkal sehingga dengan mudahnya dapat dipengaruhi. Mahasiswa baru harus dibentengi dengan pemahaman agama yang inklusif agar tidak terjangkit dengan pamahaman-pemahaman keagamaan yang ekstrim dan radikal.

Kondisi kampus tidak seharusnya diperparah dengan adanya kebijakan kampus yang tidak memberi ruang kepada mahasiswa untuk menuangkan ide-ide kritis dan kreatifitas mereka. Mahasiswa dijejali dengan serangkaian programprogram yang sistematis yang membuat mahasiswa tidak berkutik, membosankan, jenuh dan bahkan bisa menyebabkan mahasiswa stress. Kreasi dan ide-ide kritisnya tidak tersalurkan dengan baik, padahal mereka adalah generasi yang sangat membutuhkan ruang untuk menuangkan gagasan atau ide-ide kritis dan kreatif.

Ketika kritisisme dan kreatifitas mahasiswa tersebut tersumbat atau sengaja disumbat, maka sangat mungkin mahasiswa mencari escapisme (pelarian) terhadap gerakan-gerakan yang menurut mereka memberikan kebebasan berekspresi (tentu dengan pemahaman yang sangat subjektif) ataukah diekpresikan dengan demontrasidemontrasi yang anarkis.

Pihak kampus senantiasa memantau dan harus peka dalam mencermati keadaan di lingkungan aktivitas mahasiswa yang mengarah pada perilaku radikal. Misalnya memantau pesan-pesan yang disampaikan dalam forum-forum diskusi atau halaqahhalaqah yang dilakukan oleh mahasiswa.

19 Rektor Paramadina, Firmanzah, Diskusi Perspektif Indonesia, Smart FM dan Populi Center, Jakarta, Sabtu, 8 Juni 2018. 
Mencermati adanya penyebaran pesan atau selebaran yang isinya berpaham ekstrim. Karena gerakan radikalisme agama bagaikan musuh dalam selimut, hal ini dapat membahayakan kehidupan berbangsa dan umat Islam itu sendiri.

Upaya komuniasi preventif penyebaran radikalisme agama melalui media sosial hendaknya menjadi perhatian pihak kampus kepada mahasiswa pengguna media sosial agar berhenti mengikuti kampanye doktrin paham tersebut. Terkait dengan hal tersebut mantan menteri Riset, Teknologi dan Pendidikan Tinggi, Mohammad Nasir menegaskan Perguruan tinggi harus merawat empat pilar kebangsaan Negara Kesatuan Republik Indonesia (NKRI), Pancasila, Undang-undang Dasar 1945, dan Bhinneka Tunggal Ika.

Perguruan tinggi adalah tempat bagi mahasiswa yang memiliki banyak keanekaragam potensi untuk menyalurkan bakat, keahlian, pengetahuan, kepemimpinan, dan intelektual merka. Walau demikian seorang mahasiswa menyatakan bahwa sebenarnya mahasiswa masih mencari ke arah mana orientasi masa depan yang akan mereka tempuh. Sehingga mereka masih memerlukan beberapa pengaruh, masukan yang dapat menunjang dan memfasilitasi mereka untuk mencapai arah yang mereka akan tuju tersebut. Oleh karenanya mahasiswa masih mencari prinsip dan jati diri. dibalik pencarian itu, ada kalanya mahasiswa sendiri mencari kelompok radikal

Untuk mengarahkan pola pikir mahasiswa dalam preventif radikalisme agama bukan hanya tanggung jawab kampus dan pihak lembaga pendidikan semata, tetapi pemerintah sebagai penyelenggara negara juga harus memiliki tanggung jawab penuh, khususnya kementrian pendidikan dan teknologi. Sistem pendidikan yang kurang maksimal dan kurang mampu memfasilitasi nilai-nilai luhur yang terkandung dalam pancasila dan ajaran agama secara tepat menjadi celah bagi jaringan radikal untuk masuk menyebarkan pemahaman ajarannya dalam kampus.

Perguruan tinggi diperlukan revitaslisasi mata kuliah yang bersifat ideologis Pancasila, wawasan kebangsaan, dan agama. Dengan memahami ideologi Pancasila mahasiswa diarahkan untuk menumbuhkan semangat nasionalisme kebangsaan dan kewarganegaraan yang bertanggungjawab. Kemudian melalui pendidikan agama, akan diarahkan untuk penguatan perspektif keagamaan-kebangsaan yang akan diorientasikan untuk penguatan sikap intelektual tentang keragaman agama, toleransi intraagama dan antaragama serta antara umat beragama dengan negara. Mereka niscaya akan memiliki prinsip dan pandangan yang jelas dalam kehidupan berbangsa dan bernegara.

Selain dari aspek kurikulum yang patut diajarkan di lingkungan perguruan tinggi, perlu juga dikomunikasikan kepada organisasi-organisasi intra kampus agar lebih intens dan efektif memilih tema-tema sebagai objek kajiannya. Oleh karena itu, dari lingkup organisasi inilah mahasiswa akan benar-benar terlatih untuk hidup dalam suatu masyarakat yang pluralis. Dalam suatu masyarakat yang mempunyai beragam cara berinteraksi, beragam corak budaya (masyarakat multikultural) memiliki berbagai macam ide-ide kreatifitas, dan pandangan-pandangan mengenai permasalahan Negara dan 
agama. Yang tentunya semua aspek tersebut akan dibimbing ke arah yang positif dan bermanfaat. Sehingga mereka akan terlatih jiwa kepemimpinan, keuletan, kemufakatan, dan nilai-nilai nasionalisme terpatri dalam jiwa mereka.

Terkait dengan konsep jihad, mahasiswa perlu diarahkan pola pikir mereka agar tidak terkungkung kepada pemahaman yang sempit bahwa jihad itu hanya diartikan perang melawan musuh. Mahasiswa sangat penting untuk mempelajari dan mengetahui penjelasan tentang pengertian konsep jihad dalam Islam yang sebenarnya. Hal ini, tentu sangat berkaitan dengan maraknya tindakan radikalisme yang mengatasnakan agama, yang seringkali diidentikkan dengan konsep jihad di jalan Allah. Jihad merupakan media doktrinalisasi yang berfungsi sebagai alat perjuangan agama dalam menjawab tantangan zaman.

Hal yang perlu disadari, bahwa jihad bukanlah produk otoritas individu atau penafsiran organisasi tertentu, melainkan produk dari berbagai individu, dan menafsirkannya serta menerapkan dalam prinsip-prinsip hidup dalam konteks khusus secara historis politis. Untuk itu kita harus membaca dan memahami ayatayat al-Qur'an secara historis. Misalnya, kita dapat melihat ayat-ayat al-Qur'anyang membahas jihad dalam Q.S. al-Ankabut [29]: 69, "Dan orang-orang yang berjihad untuk (mencari keridhaan) Kami, benarbenar akan Kami tunjukkan kepada mereka jalan-jalan kami. dan Sesungguhnya Allah benar-benar beserta orang-orang yang berbuat baik". Kemudian dalam Q.S. alHajj [22]: 78, "Dan berjihadlah kamu pada jalan Allah dengan Jihad yang sebenarbenarnya. Dia telah memilih kamu dan Dia sekali-kali tidak menjadikan untuk kamu dalam agama suatu kesempitan. (Ikutilah) agama orang tuamu Ibrahim. Dia (Allah) telah menamai kamu sekalian orang-orang Muslim dari dahulu, dan (begitu pula) dalam (al-Qur'an) ini, supaya Rasul itu menjadi saksi atas dirimu dan supaya kamu semua menjadi saksi atas segenap manusia, Maka dirikanlah sembahyang, tunaikanlah zakat dan berpeganglah kamu pada tali Allah. Dia adalah Pelindungmu, Maka Dialah Sebaik-baik pelindung dan sebaikbaik penolong."

Kandungan pada ayat tersebut
menekankan konsep jihad sebagai perjuangan yang inhern dengan kesulitan dan kerumitan menuju kehidupan yang lebih baik. Berjuang melawan hawa nafsu di dalam diri sendiri jauh lebih sulit dalam rangka mencapai keutamaan hidup, kemakmuran, kesejahteraan baik secara ekonomi, politik dan sosial budaya.

Jihad adalah konsep ajaran Islam yang paling sering menimbulkan kontroversi di kalangan umat termasuk mahasiswa. Bagi kaum radikalis, jihad selalu bermakna "qital" atau peperangan atau perjuangan dengan mengangkat senjata. Sebenarnya makna jihad mempunyai arti yang beragam, meskipun salah satu artinya perang melawan musuh Islam. Kata jihad secara harfiah dan istilah mempunyai makna yang beragam. Dalam Ensiklopedi Islam Indonesia misalnya, makna kata jihad diartikan: berbuat sesuatu secara maksimal, atau mengorbankan segala kemampuan. Arti lain dari kata jihad adalah berjuang secara sungguh-sungguh. 
Tetapi bila dilihat dari sudut ilmu fiqh, jihad dapat dimaknai secara kontekstual sehingga bisa memiliki pengertian yang berbeda-beda.

Pemaknaan jihad yang berbeda-beda tersebut mempunyai akibat hukum syariat yang berbeda pula dan kadang bersinggungan dengan aqidah. Sebagian ulama memaknai jihad sebagai usaha "mengerahkan segala kemampuan yang ada atau sesuatu yang dimiliki untuk menegakkan kebenaran dan kebaikan serta menentang kebatilan dan kejelekan dengan mengharap ridla Allah

Islam menegaskan, jihad selain merupakan salah satu inti ajaran Islam, juga tidak bisa disimplifikasi sebagai sinonim kata qital dan harb (perang). Perang selalu merujuk kepada pertahanan diri dan perlawanan yang bersifat fisik, sementara jihad memiliki makna yang kaya nuansa. Demikian pula, sementara qital sebagai terma keagamaan baru muncul pada periode Madinah, sementara jihad telah menjadi dasar teologis sejak periode Mekah.

Dari tiga puluh enam ayat Al-Quran tentang jihad, terkandung (sekitar) tiga puluh kata j-h-d dengan segala derivasinya, tidak lebih dari sepuluh ayat yang terkait dengan perang. Selebihnya kata tersebut merujuk kepada segala aktivitas lahir dan batin, serta upaya intens dalam rangka menghadirkan kehendak Allah di muka bumi ini, yang pada dasarnya merupakan pengembangan nilai-nilai moralitas luhur, mulai penegakan keadilan hingga kedamaian dan kesejahteraan umat manusia dalam kehidupan ini. Pemaknaan ini sesuai dengan Hadis Rasulullah semisal dalam Musnad Imam Ahmad yang menegaskan bahwa mujahid adalah orang yang bersungguh-sungguh melawan subyektivitas kedirian demi untuk mentaati ajaran Allah. Dalam ungkapan lain, jihad adalah kesungguhan hati untuk mengerahkan segala kemampuan untuk membumikan nilai-nilai dan ajaran Islam dalam kehidupan. Konsep jihad inilah yang harus dibentuk arah pola pikir mahasiswa agar tidak mudahnya masuk atau mengikuti aliran pemahaman yang ekstrim dalam keberagamaan mereka.

Upaya kongkret yang perlu dikomunikasi preventif radikalisme agama di perguruan tinggi sebagaimana usaha yang akan dilakukan oleh Kemenristek Dikti melalui Permenristekdikti No. 55 Tahun 2018 merespon dengan menekankan mentoring kebangsaan bagi aktifitas mahasiswa di kampus. Setiap kampus wajib membentuk Unit Kegiatan Mahasiswa Pengawal Ideologi Bangsa (UKM-PIB). Salah satunya adalah mengajak kembali organisasi ekstra yang berhaluan Pancasila di kampus untuk ikut memperkuat upaya melawan radikalisme di kampus. UKM ini menjadi wadah bagi organisasi mahasiswa untuk berkosentrasi dalam memperkuat ideologi kebangsaan yang mulai pudar di lingkungan perguruan tinggi dengan merebaknya pemikiran radikal.

Mahasiswa menganut paham radikal dipengaruhi oleh pemahaman ajaran agama yang sempit, pertahanan ideologi dan keinginan menjalankan agama dengan baik, ketidaktegasan pihak kampus dalam memberikan pencerahan kepada mahasiswa, minimnya partisipasi 
pemerintah dalam penanganan radikalisme kaum intelektual muda, dan ketimpangan dalam sektor sosial, ekonomi, dan politik.

\section{Kesimpulan}

Setelah membahas lebih lanjut tentang upaya menangkal radikalisme agama di perguruan tinggi maka penulis dapat menyimpulkan bahwa:

1. Latar belakang mahasiswa menganut paham radikalisme antara lain: Pemahaman ajaran agama yang sempit dan dangkal, mempertahankan ideologi dan ingin menjalankan agamanya dengan baik, ketidaktegasan pihak kampus dalam memberikan pencerahan kepada mahasiswa, pemerintah kurang campur tangan dalam penanganan paham radikalisme bagi kaum intelektual muda dan adanya ketimpangan dalam sektor sosial, ekonomi dan politik.

2. Komunikasi preventif dalam upaya menangkal paham radikal adalah hendaknya pihak kampus bekerja sama dengan penerintah melakukan pembinaan terutama pada mahasiswa baru yang baru saja mengenal kampus tentang pemahaman keagamaan. Setiap perguruan tinggi seharusnya mempunyai data riil yang terkait dengan pemahaman keagamaan mahasiswa. Terkait dengan konsep jihad, mahasiswa perlu diarahkan mindset mereka agar tidak terkungkung kepada pemahaman yang sempit bahwa jihad itu hanya diartikan perang melawan musuh tetapi harus dijelaskan lebih komprehensif.

\section{Daftar Pustaka}

Abdullah, Anzar. Gerakan Radikalisme dalam Islam Perspektif Historis, Juni 10, 2019.

https://www.researchgate.net/publicatio n/304024400

Departeman Agama Republik Indonesia. Al-Qur'an dan Terjemahnya. Semarang; Yayasan Penyelenggara Penterjemah al-Qur'an, 1989.

Duriana, Studi Terhadap Idiologi Radikalisme Agama Pasca Konflik Maluku, Jurnal Fikratuna 8 no. 2, (Desember, 2016): 105-126.

Faisal, Sanapiah. Format-format Penelitian Sosial. Jakarta: Rajawali Press, 1992.

Geraudy. Al-Ushuliyah al-Ma'ashirah. Paris: Dar Alam al-Fann, 1992.

Imarah, Muhammad, Fundamentalisme dalam Perpektif Pemikiran Barat dan Islam, terj. Abdul Hayyie al-Kattani, Cet. I, Jakarta: Gema Insani Press, 1999.

Kusmanto, Thohir Yuli. "Dialektika Radikalisme dan Anti Radikalisme di Pesantren ”, Jurnal Walisongo 23 no. 1 (2015): 27-50.

https://journal.walisongo.ac.id/index. php/walisongo/article/view/221/202

Mokogenta Sihontang, Aktualisasi Nilainilai Pancasila, Dilakt Revolusi Mental Balai Diklat Keagamaan Ambon tanggal 9 September 2018. 
Moleong, Lexy J. Metodologi Penelitian

Kualitatif. Bandung: Remaja

Rosdakarya, 2000.

Nasution. Metode Penelitian Naturalistik

Kualitatif. Bandung: Tarsito, 2003.

Nata, Abudin. Peta Keragaman Pemikiran

Islam di Indonesia, cet. II. Jakarta:

Rajawali Pres, 2001.

Rahmat, M. Imdadun. Arus Baru Islam Radikal Transmisi Revivalisme Islam Timur Tengah ke Indonesia. Jakarta: Penerbit Erlangga, 2005.

Rektor Paramadina, Firmanzah, Diskusi Perspektif Indonesia. Smart FM dan Populi Center, Jakarta, Sabtu 8 Juni 2018.

Sukmadinata. Metodologi Penelitian Kualitatif. Bandung: Remaja Rosdakarya, 2006.

Zen, Fathurin. Radikalisme Retoris. Jakarta: Bumen Pustaka Emas, 2012. 